\title{
Effects of Lubiprostone on Pacemaker Activity of Interstitial Cells of Cajal from the Mouse Colon
}

\author{
Han-Yi Jiao" ${ }^{1, *}$, Dong Hyun Kim ${ }^{2, *}$, Jung Suk Ki ${ }^{1}$, Kwon Ho Ryu ${ }^{1}$, Seok Choi ${ }^{1}$, and Jae Yeoul Jun ${ }^{1}$ \\ Departments of ${ }^{1}$ Physiology, ${ }^{2}$ Radiology, College of Medicine, Chosun University, Gwangju 501-759, Korea
}

\begin{abstract}
Lubiprostone is a chloride $\left(\mathrm{Cl}^{-}\right)$channel activator derived from prostaglandin $\mathrm{E}_{1}$ and used for managing constipation. In addition, lubiprostone affects the activity of gastrointestinal smooth muscles. Interstitial cells of Cajal (ICCs) are pacemaker cells that generate slow-wave activity in smooth muscles. We studied the effects of lubiprostone on the pacemaker potentials of colonic ICCs. We used the whole-cell patch-clamp technique to determine the pacemaker activity in cultured colonic ICCs obtained from mice. Lubiprostone hyperpolarized the membrane and inhibited the generation of pacemaker potentials. Prostanoid $\mathrm{EP}_{1}, \mathrm{EP}_{2}, \mathrm{EP}_{3}$, and $\mathrm{EP}_{4}$ antagonists (SC-19220, PF-04418948, 6-methoxypyridine-2-boronc acid $N$-phenyldiethanolamine ester, and GW627368, respectively) did not block the response to lubiprostone. L-NG-nitroarginine methyl ester (L-NAME, an inhibitor of nitric oxide synthase) and $1 H$-[1,2,4]oxadiazolo[4,3,-a]quinoxalin-1-one (ODQ, an inhibitor of guanylate cyclase) did not block the response to lubiprostone. In addition, tetraethylammonium (TEA, a voltage-dependent potassium $\left[\mathrm{K}^{+}\right]$channel blocker) and apamin (a calcium $\left[\mathrm{Ca}^{2+}\right]-$ dependent $\mathrm{K}^{+}$ channel blocker) did not block the response to lubiprostone. However, glibenclamide (an ATP-sensitive $\mathrm{K}^{+}$channel blocker) blocked the response to lubiprostone. Similar to lubiprostone, pinacidil (an opener of ATP-sensitive $\mathrm{K}^{+}$channel) hyperpolarized the membrane and inhibited the generation of pacemaker potentials, and these effects were inhibited by glibenclamide. These results suggest that lubiprostone can modulate the pacemaker potentials of colonic ICCs via activation of ATP-sensitive $\mathrm{K}^{+}$channel through a prostanoid EP receptor-independent mechanism.
\end{abstract}

Key Words: Colon, Interstitial cells of Cajal, Lubiprostone, Pacemaker potentials

\section{INTRODUCTION}

Lubiprostone is a bicyclic fatty acid derivative of prostaglandin E1 used for the treatment of chronic constipation and constipation-predominant irritable bowel syndrome [1-4]. Lubiprostone exerts its effect by increasing chloride secretion in small and large intestinal epithelial cells by direct activation of chloride channel type 2 (CIC-2) or cystic fibrosis transmembrane conductance regulator (CFTR) chloride channels or via the prostaglandin E type (EP) receptor [5-10]. Active secretion of chloride into the intestinal lumen followed by a passive secretion of electrolytes and water increases the luminal fluidity, and thus accelerates the intestinal and colonic transit times and diminishes the

Received May 1, 2014, Revised July 9, 2014,

Accepted July 9, 2014

Corresponding to: Jae Yeoul Jun, Department of Physiology, College of Medicine, Chosun University, 309 Pilmun-daero, Dong-gu, Gwangju 501-375, Korea. (Tel) 82-62-230-6412, (Fax) 82-62-2324943, (E-mail) jyjun@chosun.ac.kr

*These authors contributed equally to this work.

(i) (2) This is an Open Access article distributed under the terms of the Creative Commons Attribution Non-Commercial License (http reative Commons Attribution Non-Commercial License (http// creativecommons.orgention and reproduction in any medium, provided the original work symptoms of constipation [11]. However, lubiprostone has been reported to additional activity that may modulate the smooth muscle activity. In uterine smooth muscles, lubiprostone hyperpolarized the membrane through direct activation of CIC-2 located in the smooth muscle cells [12]. Lubiprostone delayed gastric emptying but increased small and large intestinal transit times [13]. In addition, lubiprostone contracted the longitudinal smooth muscles of the stomach and inhibited neuronally mediated contractions of colonic circular smooth muscle in rats and humans [14]. Further, lubiprostone increased contractions of the smooth muscles of the small intestine via the EP receptor [15]. These results suggest that lubiprostone can modulate gastrointestinal (GI) motility by $\mathrm{Cl}^{-}$secretion-independent manner.

Interstitial cells of Cajal (ICCs) play a role in motor regulation of the GI tract by generating slow waves in smooth muscles, propagating the slow waves, translating the neural input, and detecting the stretching of intestinal lumen [16-18]. ICCs form the network in the GI tract and are connected with smooth muscles via gap junctions $[19,20]$. Thus, disruption of ICCs networks is associated with several GI motility disorders [21,22]. However, the effects and the role of lubiprostone on ICCs have not been reported thus far.

ABBREVIATIONS: ICCs, interstitial cells of Cajal; GI, gastrointestinal. 
To determine whether lubiprostone can modulate the GI motility by affecting the ICCs, we investigated the effects of lubiprostone on the pacemaker potential of colonic ICCs.

\section{METHODS}

\section{Preparation of cells}

The protocols and animal care used in these experiments were in accordance with the guiding principles approved by the ethics committee of the Chosun University and the National Institutes of Health Guide, South Korea for the Care and Use of Laboratory Animals. Mice had free access to water and a standard mouse diet until the day of experimentation. Balb/C mice ( $5 \sim 8$ days old) of either sex were anesthetized with ether and killed by cervical dislocation. The colon from below the cecum to the rectum was removed, and the middle portion of the colon was used. The colon was opened along the mesenteric border. The luminal contents were washed with Krebs-Ringer bicarbonate solution. The tissues were pinned to the base of a Sylgard dish and the mucosa was removed by sharp dissection. Small strips of the colonic muscle were equilibrated in $\mathrm{Ca}^{2+}$. free Hank's solution for $30 \mathrm{~min}$, and the cells were dispersed with an enzyme solution containing $1.3 \mathrm{mg} / \mathrm{mL}$ collagenase (Worthington Biochemical Co, Lakewood, NJ, USA), $2 \mathrm{mg} / \mathrm{mL}$ bovine serum albumin (Sigma, St. Louis, MO, USA), $2 \mathrm{mg} / \mathrm{mL}$ trypsin inhibitor (Sigma), and $0.27 \mathrm{mg} / \mathrm{mL}$ ATP. Cells were plated onto sterile glass coverslips coated with murine collagen $(2.5 \mathrm{mg} / \mathrm{mL} \mathrm{Falcon} / \mathrm{BD})$ in $35-\mathrm{mm}$ culture dishes. The cells were then cultured at $37^{\circ} \mathrm{C}$ in a $95 \%$ $\mathrm{O}_{2} / 5 \% \mathrm{CO}_{2}$ incubator in smooth muscle growth medium (SMGM; Clonetics Corp., San Diego, CA, USA) supplemented with 2\% antibiotics/antimycotics (Gibco, Grand Island, NY, USA) and $5 \mathrm{ng} / \mathrm{mL}$ urine stem cell factor (SCF, Sigma).

\section{Labeling of cultured colonic ICCs by using c-kit im- munofluoresence}

Cultured ICCs were fixed in acetone $\left(20^{\circ} \mathrm{C} / 5 \mathrm{~min}\right)$. Following fixation, preparations were washed for $60 \mathrm{~min}$ in phosphate-buffered saline (PBS; $0.01 \mathrm{M}$, pH 7.4). Cultured ICCs were then incubated in $10 \%$ goat serum containing $1 \%$ bovine serum albumin for $1 \mathrm{~h}$ at room temperature (RT) to reduce nonspecific antibody binding. The cultured ICCs were incubated overnight at $4^{\circ} \mathrm{C}$ with a rat monoclonal antibody raised against Kit protein $\left(\mathrm{ACK}_{2} ; 5 \mu \mathrm{g} / \mathrm{mL}\right.$ in PBS; Gibco-BRL, Gaithersburg, MD, USA). Immunoreactivity was detected using fluorescein isothiocyanate (FITC)-conjugated secondary antibody (FITC-anti-rat; Vector Laboratories, 1:100 in PBS, $1 \mathrm{~h}$ at RT). Control cultured ICCs were prepared in a similar manner, except incubation with $\mathrm{ACK}_{2}$. Cells were examined under a confocal laser-scanning microscope (FV300; Olympus, Japan) at an excitation wavelength appropriate for FITC $(488 \mathrm{~nm})$.

\section{Patch-clamp experiments}

The whole-cell configuration of the patch-clamp technique was used to record pacemaker potentials in colonic ICCs that showed the network-like structures in culture (2 $\sim 3$ days). Pacemaker potentials were amplified using Axopatch 200B (Axon Instruments, Foster, CA, USA). The data were filtered at $5 \mathrm{kHz}$ and displayed on a computer monitor. The results were analyzed using pClamp and GraphPad Prism software (version 2.01, GraphPad Software Inc., San Diego, CA, USA). All experiments were performed at $30^{\circ} \mathrm{C}$.

\section{Reagents}

The cells were bathed in a solution containing $5 \mathrm{mM} \mathrm{KCl}$,

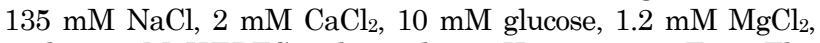
and $10 \mathrm{mM}$ HEPES, adjusted to $\mathrm{pH} 7.2$ using Tris. The pipette solution contained $20 \mathrm{mM}$ potassium aspartate, 120 $\mathrm{mM} \mathrm{KCl}, 5 \mathrm{mM} \mathrm{MgCl}_{2}, 2.7 \mathrm{mM} \mathrm{K} \mathrm{K}_{2} \mathrm{ATP}, 0.1 \mathrm{mM} \mathrm{Na} 2 \mathrm{GTP}$, $2.5 \mathrm{mM}$ creatine phosphate disodium, $5 \mathrm{mM}$ HEPES, and $0.1 \mathrm{mM}$ EGTA, adjusted to $\mathrm{pH} 7.2$ using Tris.

The drugs used were lubiprostone, SC-19220, PF-04418948, 6-methoxypyridine-2-boronc acid $N$-phenyldiethanolamine ester, GW627368, glibenclamide, L-NG-nitroarginine methyl ester (L-NAME), H-[1,2,4]oxadiazolo[4,3,-a]quinoxalin-1one (ODQ), tetraethylammonium (TEA), apamin, pinacidil, and glibenclamide. PF-04418948 and GW627368 were purchased from Cayman Chemical (Cambridge, UK) and lubiprostone was purchased from Calbiochem (San Diego, CA, USA) and the other compounds were purchased from Sigma.

\section{Statistical analysis}

Data are expressed as the means \pm standard errors. Differences in the data were evaluated using the Student's $t$ test. A p-value $<0.05$ was considered to indicate a statistically significant difference. The $n$ values reported in the text refer to the number of cells used in the patch-clamp experiments.

\section{RESULTS}

\section{Lubiprostone inhibits pacemaker potentials in colonic ICCs}

The patch-clamp technique was used to examine the ICCs that showed network-like structures in culture ( $2 \sim 3$ days), and these structures were identified by immunostaining for

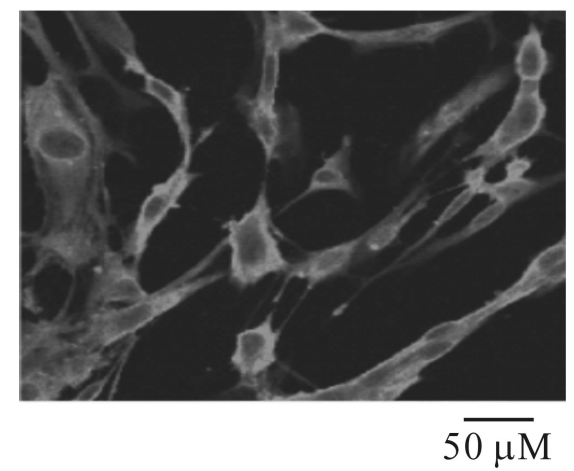

Fig. 1. Cultured interstitial cells of Cajal (ICCs) from the mouse colon. The tunica muscularis of the colon was digested with collagenase, and the dispersed cells were cultured for 2 days. Confocal microscopic image of Kit-immunopositive ICCs network in culture. 


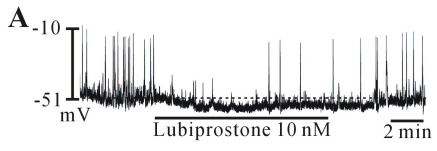

D

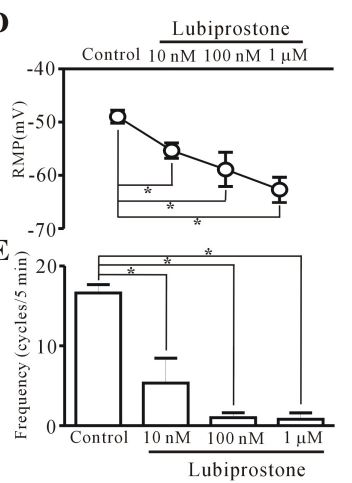

Fig. 2. Effects of lubiprostone on pacemaker potentials in cultured interstitial cells of Cajal (ICCs) from the mouse colon. $(\mathrm{A} \sim \mathrm{C})$ Pacemaker potentials from ICCs exposed to lubiprostone (10 nM to $1 \mu \mathrm{M}$ ) in current clamping. Lubiprostone caused a concentrationdependent hyperpolarization of the membrane and inhibited the generation of pacemaker potentials. The responses to lubiprostone are summarized in D and E. Bars represent mean values \pm standard error (SE). ${ }^{*}(p<0.05)$ Significantly different from the untreated control. The dotted lines indicate the resting membrane potentials.

kit protein (Fig. 1). In the current clamping mode, colonic ICCs generated spontaneous periodic pacemaker potentials (Fig. 2). To understand the relationship between lubiprostone and the modulation of pacemaker potentials in ICCs, we examined the effects of lubiprostone on pacemaker potentials. Under control conditions, the resting membrane potential was $-48.9 \pm 1.2 \mathrm{mV}$, the frequency and amplitude of pacemaker potentials were $15.6 \pm 1.1$ cycles $/ 5 \mathrm{~min}$ and $40.8 \pm 5.3 \mathrm{mV}$, respectively $(\mathrm{n}=16)$. The addition of lubiprostone (10 $\mathrm{nM}$ to $1 \mu \mathrm{M}$ ) hyperpolarized the membrane and inhibited the generation of pacemaker potentials in a concentration-dependent manner (Fig. $2 \mathrm{~A} \sim \mathrm{C}$ ). In the presence of lubiprostone, the resting membrane potential was -55.4 $\pm 1.4 \mathrm{mV}$ at $10 \mathrm{nM},-58.9 \pm 3.2 \mathrm{mV}$ at $100 \mathrm{nM}$, and $-63.3 \pm$ $2.3 \mathrm{mV}$ at $1 \mu \mathrm{M}$ (Fig. 2D), and the frequency was $5.3 \pm 3.1$ cycles $/ 5 \mathrm{~min}$ at $10 \mathrm{nM}, 1.0 \pm 0.6 \mathrm{cycles} / 5 \mathrm{~min}$ at $100 \mathrm{nM}$, and $0.8 \pm 0.8$ cycles $/ 5 \mathrm{~min}$ at $1 \mu \mathrm{M}$ (Fig. $2 \mathrm{E}$ ). These results suggest that lubiprostone inhibits pacemaker potentials in colonic ICCs.

\section{Prostanoid EP receptors are not involved in lubipro- stone-induced inhibition of pacemaker potential}

To determine whether the action of lubiprostone was mediated by the prostanoid EP receptor, we examined the effects of selective EP receptor antagonists. We used SC-19220 (an $\mathrm{EP}_{1}$ receptor antagonist), PF-04418948 (an $\mathrm{EP}_{2}$ receptor antagonist), 6-methoxypyridine-2-boronc acid $N$-phenyldiethanolamine ester (an $\mathrm{EP}_{3}$ receptor antagonist), and GW627368 (an $\mathrm{EP}_{4}$ receptor antagonist). Pretreatment of cells with SC-19220 (5 $\mu \mathrm{M} ; \mathrm{n}=5)$, PF-04418948 (10 $\mu \mathrm{M} ; \mathrm{n}=6), 6$-methoxypyridine-2-boronc acid $N$-phenyldiethanolamine ester $(10 \mu \mathrm{M} ; \mathrm{n}=6)$, and GW627368 (10 $\mu \mathrm{M}$; $\mathrm{n}=6$ ) had no effect on the pacemaker potentials and did not block the lubiprostone-induced responses (Fig. 3A D). Lubiprostone continued to inhibit the pacemaker potentials in the presence of EP receptor antagonists. The results of these experiments are shown in Fig. $3 \mathrm{E}$ and $3 \mathrm{~F}$. These results suggest that prostanoid EP receptors may not be involved in lubiprostone-induced inhibition of pacemaker po-
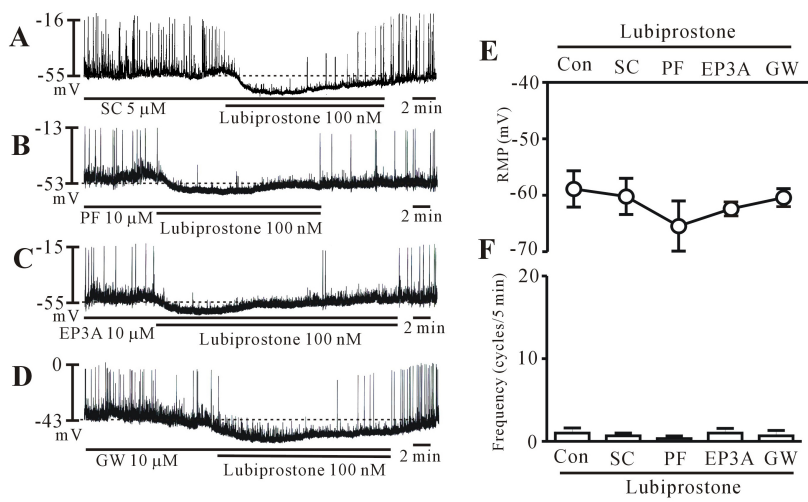

Fig. 3. Effects of prostanoid EP receptor antagonists on lubiprostone-induced responses of pacemaker potentials in cultured interstitial cells of Cajal (ICCs) of the mouse colon. (A $\sim \mathrm{D})$ Pacemaker potentials from ICCs exposed to lubiprostone (100 nM) in the presence of prostanoid EP receptor antagonists. SC-19220 (an $\mathrm{EP}_{1}$ receptor antagonist; $5 \mu \mathrm{M}$ ), PF-04418948 (an $\mathrm{EP}_{2}$ receptor antagonist; $10 \mu \mathrm{M}), 6$-methoxypyridine-2-boronc acid $N$-phenyldiethanolamine ester (an $\mathrm{EP}_{3}$ receptor antagonist; $10 \mu \mathrm{M}$ ), and GW627368 (an $\mathrm{EP}_{4}$ receptor antagonist; $10 \mu \mathrm{M}$ ) did not block the lubiprostone-induced responses on pacemaker potentials. The responses to lubiprostone in the presence of EP receptor antagonists are summarized in (E) and (F). Bars represent mean values \pm standard error (SE). The dotted lines indicate the resting membrane potentials (SC, SC-19220; PE, PF-04418948; EP3A, 6-methoxypyridine-2-boronc acid $N$-phenyldiethanolamine ester; GW, GW627368).

tential in colonic ICCs.

\section{Nitric oxide and cGMP are not involved in lubipro- stone-induced inhibition of pacemaker potential}

Nitric oxide (NO) and intracellular cGMP inhibit the pacemaker potentials in colonic ICCs. Thus, to elucidate whether lubiprostone-induced responses were mediated by the release of NO or intracellular cGMP, we tested L-NAME, an inhibitor of NO synthase and ODQ, an inhibitor of guanylate cyclase. Both L-NAME $(100 \mu \mathrm{M} ; \mathrm{n}=6)$ and ODQ (10 $\mu \mathrm{M} ; \mathrm{n}=5)$ depolarized the membrane and increased the pacemaker potential frequency. However, lubiprostone continued to inhibit the pacemaker potentials in the presence of L-NAME and ODQ (Fig. 4A and 4B). The results are shown in Fig. $4 \mathrm{C}$ and $4 \mathrm{D}$. These results suggest that NO and intracellular cGMP may not be involved in lubiprostone-induced inhibition of pacemaker potentials in the colonic ICCs.

\section{Voltage-dependent $\mathrm{K}^{+}$channels and $\mathrm{Ca}^{2+}$-activated $\mathrm{K}^{+}$ channels are not involved in lubiprostone-induced inhibition of pacemaker potential}

To determine whether lubiprostone affects $\mathrm{K}^{+}$channels in ICCs, we treated the ICCs with TEA (a voltage-dependent $\mathrm{K}^{+}$channel blocker) and apamin (a small conductance $\mathrm{K}^{+}$channel blocker). TEA $5 \mathrm{mM}(\mathrm{n}=4)$ and apamin $100 \mathrm{nM}$ $(n=5)$ did not block the response to lubiprostone (Fig. 5A and $\mathrm{B}$ ). The results are shown in Fig. 5C and 5D. These results suggest that $\mathrm{Ca}^{2+}$-activated $\mathrm{K}^{+}$channel and voltage-dependent $\mathrm{K}^{+}$channels may not be involve in lubiprostone-induced inhibition of pacemaker potential in colonic 


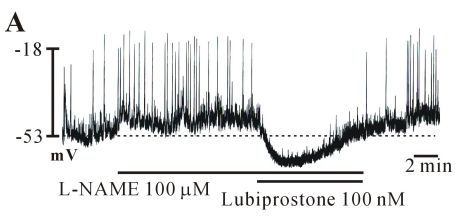

C
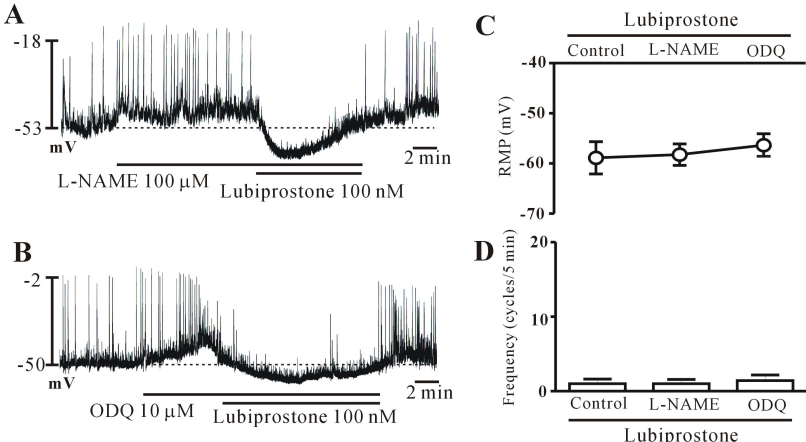

Fig. 4. Effects of ${ }_{L}-\mathrm{NG}$-nitroarginine methyl ester (L-NAME) and $\mathrm{H}-[1,2,4]$ oxadiazolo[4,3,-a]quinoxalin-1-one (ODQ) on lubiprostoneinduced responses on pacemaker potentials in cultured interstitial cells of Cajal (ICCs) of the mouse colon. (A, B) Pacemaker potentials from ICCs exposed to lubiprostone $(100 \mathrm{nM})$ in the presence of L-NAME and ODQ. L-NAME $(100 \mu \mathrm{M})$ and ODQ $(10 \mu \mathrm{M})$ depolarized the membrane and increased the pacemaker potential frequency. However, lubiprostone continued to inhibit the pacemaker potentials in the presence of $\mathrm{L}$-NAME and ODQ. The responses to lubiprostone in the presence of ${ }_{\mathrm{L}}$-NAME and ODQ are summarized in (C) and (D). Bars represent mean values \pm standard error (SE). The dotted lines indicate the resting membrane potentials.

$\mathrm{ICCs}$.

\section{Lubiprostone activates ATP-sensitive $K^{+}$channels in colonic ICCs}

To determine whether lubiprostone affects ATP- sensitive $\mathrm{K}^{+}$channels in colonic ICCs, we used an ATP-sensitive $\mathrm{K}^{+}$ channel opener (pinacidil) and blocker (glibenclamide). Glibenclamide $(10 \mu \mathrm{M})$ blocked the lubiprostone-induced inhibition of pacemaker potential ( $\mathrm{n}=6$, Fig. 6A). In addition, pinacidil (100 $\mathrm{nM}$ ) hyperpolarized the membrane and inhibited pacemaker potentials and blocked by glibenclamide, an effect similar to that of lubiprostone on pacemaker potential (n=4, Fig. 6B). The results are shown in Fig. 6C and $6 \mathrm{D}$. These results suggest that lubiprostone activates ATP-sensitive $\mathrm{K}^{+}$channels in colonic ICCs.

\section{DISCUSSION}

Lubiprostone relieves constipation by secreting fluids and electrolytes into the intestinal lumen by opening the $\mathrm{Ca}^{2+}$. activated $\mathrm{Cl}^{-}$channel. However, previous studies reported that lubiprostone has an additional role in regulating the tone of smooth muscles. ICCs are pacemaker cells that generate slow waves in smooth muscles, and thus play an important role in regulating the GI motility. In this study, we showed that lubiprostone affected the pacemaker potentials of colonic ICCs. The inhibitory action of lubiprostone on pacemaker potentials is mediated by the activation of ATP-sensitive $\mathrm{K}^{+}$channels through a prostanoid EP receptor-independent mechanism.

Lubiprostone is a derivative of prostaglandin $\mathrm{E}_{1}$, and thus the mechanism of action of lubiprostone was thought to be mediated by the four different subtypes of EP receptors $\mathrm{EP}_{1}, \mathrm{EP}_{2}, \mathrm{EP}_{3}$, and $\mathrm{EP}_{4}$ [23]. Lubiprostone enhances intestinal $\mathrm{Cl}^{-}$secretion, duodenal bicarbonate secretion,
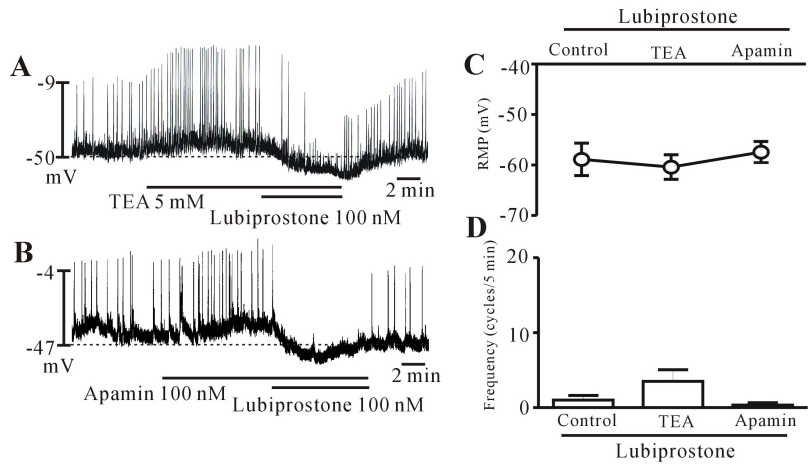

Fig. 5. Effects of tetraethylammonium (TEA) and apamin on lubiprostone-induced responses on pacemaker potentials in cultured interstitial cells of Cajal (ICCs) of the mouse colon. (A) TEA $(5 \mathrm{mM})$ and $(\mathrm{B})$ apamin $(100 \mathrm{nM})$ did not block the effects of lubiprostone $(100 \mathrm{nM})$ on pacemaker potentials. The responses to lubiprostone in the presence of TEA and apamin are summarized in (C) and (D). Bars represent mean values \pm standard error (SE). The dotted lines indicate the resting membrane potentials.
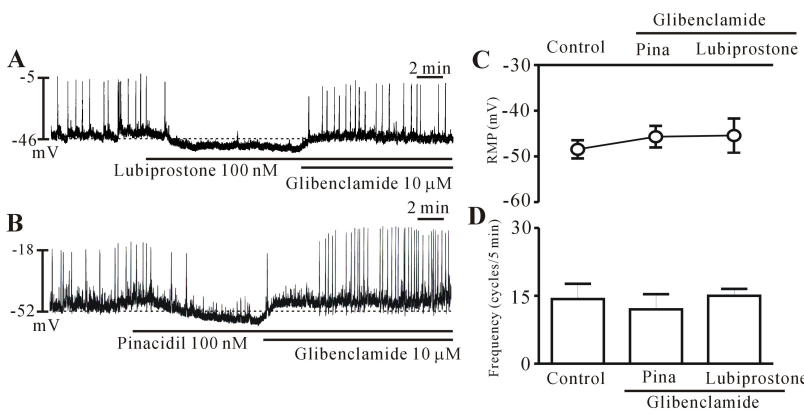

Fig. 6. Effects of glibenclamide on lubiprostone-induced responses and pinacidil effects on pacemaker potentials in cultured interstitial cells of Cajal (ICCs) of the mouse colon. (A) Glibenclamide $(10 \mu \mathrm{M})$ inhibited the lubiprostone-induced responses on pacemaker potentials. (B) Pinacidil (100 nM) hyperpolarized the membrane and inhibited the pacemaker potentials, which were blocked by glibenclamide. The responses to glibenclamide in the lubiprostone- or pinacidil-induced effects are summarized in (C) and (D). Bars represent mean values \pm standard error (SE). The dotted lines indicate the resting membrane potentials (pina, pinacidil).

and fluid secretion in the submucosal glands of the airway via activation of $\mathrm{EP}_{4}$ receptor $[6,24,25]$. In addition, lubiprostone contracts the gastric muscles and intestinal smooth muscles via activation of the $\mathrm{EP}_{1}$ receptor and inhibits colonic muscle contraction via activation of the $\mathrm{EP}_{4}$ receptor $[14,15]$. Previously, we showed that $\mathrm{PGE}_{2}$ inhibits pacemaker activity via activation of $\mathrm{EP}_{2}$ receptor in the intestinal ICCs and confirmed the existence of $\mathrm{EP}_{2}$ receptor using reverse-transcription polymerase chain reaction (RTPCR) [26]; our findings suggested that prostaglandin could modulate the GI motility by changing the electrical activity of ICCs. Our results showed that lubiprostone hyperpolarized the membrane and inhibited the generation of pacemaker potentials in colonic ICCs. However, the inhibitory action of lubiprostone on colonic ICCs was not blocked by the selective $\mathrm{EP}_{1,2,3}$, and 4 receptor antagonists. These findings suggested that the EP receptor was not involved in the lubiprostone-induced inhibition of pacemaker 
potential in colonic ICCs. The direct action of lubiprostone on CIC-2 has been reported in uterine smooth muscles [12].

NO is a major inhibitory neurotransmitter in the GI tract. The NO action is mediated through intracellular cGMP via activation of guanylate cyclase. In colonic ICCs, intracellular basal cGMP modulates the pacemaker potential frequency via continuous release of NO. $S$-nitroso- $N$ acetylpenicillamine (SNAP), a NO donor, showed effects similar to those of lubiprostone. SNAP hyperpolarized the membrane and inhibited the pacemaker potential frequency in colonic ICCs. In contrast, $\mathrm{L}$-NAME and ODQ increased the pacemaker potential frequency in colonic ICCs [27]. Therefore, we thought that the lubiprostone-induced responses observed in this study might be mediated by the NO/cGMP signaling pathway. However, lubiprostone continued to hyperpolarized the membrane and inhibit the generation of pacemaker potentials in the presence of L-NAME and ODQ, which suggested that NO or cGMP were not involved in the lubiprostone-induced inhibitory action on colonic ICCs.

$\mathrm{K}^{+}$channel activation hyperpolarizes the membrane and relaxes the smooth muscles. ICCs have small conductance $\mathrm{Ca}^{2+}$-activated $\mathrm{K}^{+}$channels, large conductance $\mathrm{K}^{+}$channels, and ATP-sensitive $\mathrm{K}^{+}$channels [28-30]. In the present study, TEA and apamin did not block the response to lubiprostone. However, glibenclamide blocked the lubiprostone-induced inhibitory actions. Furthermore, pinacidil hyperpolarized the membrane and inhibited the generation of pacemaker potentials, which were blocked by glibenclamide. These findings strongly suggest that lubiprostoneinduced action in the colonic ICCs was mediated through activation of ATP-sensitive $\mathrm{K}^{+}$channels. Activation of ATP-sensitive $\mathrm{K}^{+}$channels in the intestinal ICCs induces hyperpolarization of the membrane and abolishes the generation of pacemaker activity [31].

Lubiprostone is a $\mathrm{Cl}^{-}$channel activator used for the treatment of chronic constipation. In the present study, we were unable to determine how the inhibition of pacemaker potentials by lubiprostone is involved in relieving and treating constipation. However, the inhibition of pacemaker potentials may facilitate the transit of intraluminal contents since the colon is not contracted to induce resistance to flow. Misiewicz et al. [32] reported that patients with diarrhea had lower contractional activity of the colon after a meal, relative to healthy controls. In addition, the neuronally mediated contractions of circular smooth muscles of the colon in rats and humans were inhibited by lubiprostone [14]. Therefore, we believe that the increased secretion of fluids and electrolytes and the inhibition of pacemaker potentials by lubiprostone may play a role in relieving constipation.

In conclusion, lubiprostone inhibited the pacemaker potential via activation of ATP-sensitive $\mathrm{K}^{+}$channels through a prostaglandin EP receptor-independent mechanism. These findings suggest that although lubiprostone is a $\mathrm{Cl}^{-}$channel activator, lubiprostone has an additional role in modulating the generation of pacemaker potentials in colonic ICCs.

\section{ACKNOWLEDGEMENTS}

This study was supported by fund from Chosun University, 2011.

\section{REFERENCES}

1. McKeage K, Plosker GL, Siddiqui MA. Lubiprostone. Drugs. 2006;66:873-879.

2. Lacy BE, Chey WD. Lubiprostone: chronic constipation and irritable bowel syndrome with constipation. Expert Opin Pharmacother. 2009;10:143-152.

3. Carter NJ, Scott LJ. Lubiprostone: in constipation-predominant irritable bowel syndrome. Drugs. 2009;69:1229-1237.

4. Schey R, Rao SS. Lubiprostone for the treatment of adults with constipation and irritable bowel syndrome. Dig Dis Sci. 2011; $56: 1619-1625$.

5. Crowell MD, Harris LA, DiBaise JK, Olden KW. Activation of type-2 chloride channels: a novel therapeutic target for the treatment of chronic constipation. Curr Opin Investig Drugs. 2007;8:66-70.

6. Bijvelds MJ, Bot AG, Escher JC, De Jonge HR. Activation of intestinal $\mathrm{Cl}^{-}$secretion by lubiprostone requires the cystic fibrosis transmembrane conductance regulator. Gastroenterology. 2009;137:976-985.

7. Fei G, Wang YZ, Liu S, Hu HZ, Wang GD, Qu MH, Wang XY, Xia Y, Sun X, Bohn LM, Cooke HJ, Wood JD. Stimulation of mucosal secretion by lubiprostone (SPI-0211) in guinea pig small intestine and colon. Am J Physiol Gastrointest Liver Physiol. 2009;296:G823-832.

8. Norimatsu Y, Moran AR, MacDonald KD. Lubiprostone activates CFTR, but not ClC-2, via the prostaglandin receptor (EP(4)). Biochem Biophys Res Commun. 2012;426:374-379.

9. Lembo AJ, Schneier HA, Shiff SJ, Kurtz CB, MacDougall JE, Jia XD, Shao JZ, Lavins BJ, Currie MG, Fitch DA, Jeglinski BI, Eng P, Fox SM, Johnston JM. Two randomized trials of linaclotide for chronic constipation. N Engl J Med. 2011;365: 527-536.

10. Ao M, Venkatasubramanian J, Boonkaewwan C, Ganesan N, Syed A, Benya RV, Rao MC. Lubiprostone activates $\mathrm{Cl}^{-}$ secretion via cAMP signaling and increases membrane CFTR in the human colon carcinoma cell line, T84. Dig Dis Sci. 2011;56:339-351.

11. Lacy BE, Levy LC. Lubiprostone: a chloride channel activator. J Clin Gastroenterol. 2007;41:345-351.

12. Cuppoletti J, Malinowska DH, Chakrabarti J, Ueno R. Effects of lubiprostone on human uterine smooth muscle cells. Prostaglandins Other Lipid Mediat. 2008;86:56-60.

13. Camilleri M, Bharucha AE, Ueno R, Burton D, Thomforde GM, Baxter K, McKinzie S, Zinsmeister AR. Effect of a selective chloride channel activator, lubiprostone, on gastrointestinal transit, gastric sensory, and motor functions in healthy volunteers. Am J Physiol Gastrointest Liver Physiol. 2006;290:G942947.

14. Bassil AK, Borman RA, Jarvie EM, McArthur-Wilson RJ, Thangiah R, Sung EZ, Lee K, Sanger GJ. Activation of prostaglandin EP receptors by lubiprostone in rat and human stomach and colon. Br J Pharmacol. 2008;154:126-135.

15. Chan WW, Mashimo H. Lubiprostone Increases Small Intestinal Smooth Muscle Contractions Through a Prostaglandin E Receptor 1 (EP1)-mediated Pathway. J Neurogastroenterol Motil. 2013;19:312-318.

16. Thomsen L, Robinson TL, Lee JC, Farraway LA, Hughes MJ, Andrews DW, Huizinga JD. Interstitial cells of Cajal generate a rhythmic pacemaker current. Nat Med. 1998;4:848-851.

17. Sanders KM, Koh SD, Ward SM. Interstitial cells of cajal as pacemakers in the gastrointestinal tract. Annu Rev Physiol. 2006;68:307-343.

18. Kim BJ, Kwon YK, Kim E, So I. Effects of histamine on cultured interstitial cells of cajal in murine small intestine. Korean J Physiol Pharmacol. 2013;17:149-156.

19. Rumessen JJ, Thuneberg L. Pacemaker cells in the gastrointestinal tract: interstitial cells of Cajal. Scand J Gastroenterol Suppl. 1996;216:82-94.

20. Komuro T. Structure and organization of interstitial cells of Cajal in the gastrointestinal tract. J Physiol. 2006;576:653-658.

21. Jain D, Moussa K, Tandon M, Culpepper-Morgan J, Proctor 
DD. Role of interstitial cells of Cajal in motility disorders of the bowel. Am J Gastroenterol. 2003;98:618-624.

22. Farrugia G. Interstitial cells of Cajal in health and disease. Neurogastroenterol Motil. 2008;20 Suppl 1:54-63.

23. Dey I, Lejeune M, Chadee K. Prostaglandin E2 receptor distribution and function in the gastrointestinal tract. $\mathrm{Br} J$ Pharmacol. 2006;149:611-623.

24. Mizumori M, Akiba Y, Kaunitz JD. Lubiprostone stimulates duodenal bicarbonate secretion in rats. Dig Dis Sci. 2009;54: 2063-2069.

25. Cuthbert AW. Lubiprostone targets prostanoid $\mathrm{EP}_{4}$ receptors in ovine airways. $B r J$ Pharmacol. 2011;162:508-520.

26. Choi S, Yeum CH, Chang IY, You HJ, Park JS, Jeong HS, So I, Kim KW, Jun JY. Activating of ATP-dependent $\mathrm{K}^{+}$channels comprised of K(ir) 6.2 and SUR $2 \mathrm{~B}$ by $\mathrm{PGE}_{2}$ through EP2 receptor in cultured interstitial cells of Cajal from murine small intestine. Cell Physiol Biochem. 2006;18:187-198.

27. Shahi PK, Choi S, Jeong YJ, Park CG, So I, Jun JY. Basal cGMP regulates the resting pacemaker potential frequency of cultured mouse colonic interstitial cells of Cajal. Naunyn Schmiedebergs Arch Pharmacol. 2014;387:641-648.
28. Fujita A, Takeuchi T, Saitoh N, Hanai J, Hata F. Expression of $\mathrm{Ca}^{2+}$-activated $\mathrm{K}^{+}$channels, SK3, in the interstitial cells of Cajal in the gastrointestinal tract. Am J Physiol Cell Physiol. 2001;281:C1727-1733.

29. Lyford GL, Farrugia G. Ion channels in gastrointestinal smooth muscle and interstitial cells of Cajal. Curr Opin Pharmacol. 2003;3:583-587.

30. Nakayama S, Ohya S, Liu HN, Watanabe T, Furuzono S, Wang J, Nishizawa Y, Aoyama M, Murase N, Matsubara T, Ito Y, Imaizumi Y, Kajioka S. Sulphonylurea receptors differently modulate ICC pacemaker $\mathrm{Ca}^{2+}$ activity and smooth muscle contractility. J Cell Sci. 2005;118:4163-4173.

31. Park CG, Kim YD, Kim MY, Kim JS, Choi S, Yeum CH, Parajuli SP, Park JS, Jeong HS, So I, Kim KW, Jun JY. Inhibition of pacemaker currents by nitric oxide via activation of ATP-sensitive $\mathrm{K}^{+}$channels in cultured interstitial cells of Cajal from the mouse small intestine. Naunyn Schmiedebergs Arch Pharmacol. 2007;376:175-184.

32. Misiewicz JJ, Connell AM, Pontes FA. Comparison of the effect of meals and prostigmine on the proximal and distal colon in patients with and without diarrhoea. Gut. 1966;7:468-473. 